\title{
Obstacles to the formation of a common electricity market of the Eurasian Economic Union
}

\author{
Arthur Gibadullin ${ }^{1 *}$ and Valentina Pulyaeva ${ }^{2}$ \\ ${ }^{1}$ State University of Management, Ryazansky Prospect, 99, Moscow, Russia \\ ${ }^{2}$ Financial University under the Government of the Russian Federation, 49 Leningradsky Prospect, Moscow, Russia
}

\begin{abstract}
The current state of the economy and society is influenced by the global integration processes taking place in Eurasia - the creation of the Eurasian Economic Union, which should unite the markets for resources, goods and capital of the member states of the Eurasian Economic Union. One of the aspects of this process is the creation of a unified electricity market, which ensures free flow of electrical energy, free pricing and competition in the power industry. The purpose of this study is to study the degree of readiness of national energy systems for integration and to identify problems that impede the formation of the Common Electricity Market of the Eurasian Economic Union. The methods used were statistical analysis tools, a graphical method, comparisons and descriptions. The study was carried out on the basis of the use of information provided in the open access of the Eurasian Economic Union, national statistical services and energy companies. The authors have identified the main goals and objectives, as well as the requirements and expected results of the creation of the Common Electricity Market. As a result of the analysis of national power systems, a number of problems were identified that impede their convergence, including inconsistencies in the scale of production, various pricing mechanisms and electricity price regulation, differences in the energy balance of the Eurasian Economic Union member states, different levels of electricity prices, and a particular opinion Of the Republic of Belarus to the concept of market formation and the lack of unified borders of Armenia with other participating countries Union. The findings of the study indicate that by the stated date, namely July 1, 2019, the Common Electricity Market will most likely not be created for the reasons stated. To solve the identified problems, the authors propose several tools, one of the most important among them is the mechanism of regulatory and legal regulation of electricity markets at the national and supranational levels. Also, according to the authors, in the integration processes in the framework of the Eurasian Economic Union should consider the world experience of such political and economic associations.
\end{abstract}

\section{Introduction}

The development of the electric power complex of the Russian Federation began in the period of the existence of the Russian Empire and the absence of state plans to create and integrate the electric power complex into a single national complex. This stage was marked by the construction of private power stations, the launch of the first electric trams and large-scale street lighting. After the October Revolution of 1917, a state plan was adopted for the electrification of Russia, thanks to which the active phase of the construction and development of the electric power complex began not only within the Russian Federation, but also in the entire Soviet Union. The turbulent period of development of the electric power industry was interrupted in 1941 and resumed only after the 50s of the XX century. During the period from 1955 to 1985 , the current potential of the electric power industry of the republics of the Soviet Union was formed and, in fact, new types of activity were created related to the development of the electric power complex. After the collapse of the Soviet Union, the electric power industry of the Russian Federation was transferred to state ownership, namely, the company that managed $95 \%$ of the industry's assets - RAO UES of Russia. After the restructuring of RAO UES of Russia, competitive and monopolistic activities were formed in the power industry of Russia, and part of the production capacity was transferred to private management and is currently developing according to its own plans and programs. Most of the electric power complexes spun off from the Soviet Union have also been reformed, and are now governed by their national rules and laws $[3 ; 8 ; 9$; 13].

Today, there are processes associated with the return of national electric power complexes to a single complex, which will increase energy security, ensure the reliability and continuity of power supply to consumers, increase competitiveness and develop market relations in the industry. Similar processes occur due to the development of integration groupings at the national level, which today already exist within the framework of 
the Commonwealth of Independent States and the Eurasian Economic Union. For example, the CIS was formed in 1993 and it was assumed that a single energy market would operate within the Union, however, the plans that had been conceived were not realized. The next step in creating a single energy market is the decision of the Eurasian Economic Union to form the Common Electricity Market of the Eurasian Economic Union, according to which it was assumed that the market would be launched on July 1, 2019 [1].

\section{Materials and methods}

The purpose of this study is to analyze the electricity markets of the member states of the Eurasian Economic Union and identify obstacles to the formation of the Common Electricity Market of the Eurasian Economic Union. To achieve this goal, we have proposed the following tasks:

- analyze the national electric power complexes of the member states of the Eurasian Economic Union;

- identify and form obstacles to the creation of a Common Electricity Market of the Eurasian Economic Union.

The study was based on the methods of historical, analytical, factor, comparative, statistical, logical, economic-mathematical and system analysis, the method of expert estimates, which revealed the obstacles to the formation of the Common Electricity Market of the Eurasian Economic Union.

\section{Results}

The Common Electricity Market of the Eurasian Economic Union is a system that provides relationships between the main actors of the national electric power markets of the Union, which will be associated with the sale and purchase of electrical energy based on the developed and existing legal regulations and contracts.

It is accepted that the formation of the EAEU market should be subject to the following requirements:

- preservation of existing relations between the EAEU member states;

- preservation of the characteristics of the functioning of electric power complexes and markets of national states; - ensuring priority order of power supply to domestic consumers;

- formation of a common market considering world experience and requirements of national states.

The main objectives of the formation of a common market for electrical energy of the EAEU are as follows:

- ensuring the sustainable operation of the energy systems of national states and the development of the national economy;

- improving the reliability, continuity, efficiency and efficiency of energy facilities;

- formation of competitive advantages in the whole of the EAEU and in the global energy market;

- creation of a single space in the development of the electric power complex;
- preservation of the volumes of satisfying the demand for electric energy among the participants of national markets and the Common Electricity Market of the EAEU;

- ensuring and developing economic interests among the member states of the Common Market for Electric Power of the EAEU on the basis of the principle of fair competition.

The objectives of the formation of the Common Electricity Market of the EAEU are:

- development of market relations in the electric power complex of national states and at the level of the EAEU;

- formation of conditions for the development of national economies;

- creation of competitive market relations between the participants of the Common Electricity Market of the Eurasian Economic Union;

- development of transparent pricing principles in the power industry;

- creation of conditions for access to all subjects of natural monopolies of the EAEU member states, while not violating the principles of operation of national electric power complexes;

- creation of conditions for mutual trade in electric energy;

- reducing the growth rate of energy prices for different categories of consumers;

- formation of a favorable investment climate in the national electric power complexes.

The main result of the creation of the Common Electricity Market should be:

- ensuring the development of the national power industry and economy;

- improving the efficiency and reliability of electric power complexes;

- meeting the demand for electrical energy;

- formation of competitiveness of national industries in the international economic arena;

- provision of interstate electric power flows to isolated and energy deficient areas;

- improving the efficiency of market mechanisms and the development of competition in the national and general electricity markets;

- reduction of tariff growth rates and increase of pricing transparency in the electric power industry;

- formation of a favorable investment environment in the EAEU member countries;

- increasing the transition to innovative technologies and renewable energy $[2 ; 3 ; 4 ; 5 ; 7]$.

The functions of the system and network operators can be carried out by one organization if this is provided for by the legislation of the Member States.

The rights and obligations of the EAEU Common Electricity Market subjects are established by the legislation of the Member States in the field of electric power industry, as well as acts regulating the Common Electricity Market of the EAEU [4].

The stated goals are certainly relevant not only for the supranational electric energy market, but also for the electric power industry of the Russian Federation, perhaps by creating the Common Electric Power Market 
of the EAEU, these issues will be resolved faster and more efficiently.

However, it is worth considering the obstacles associated with the process of convergence of national industries in the Common Market of Electric Energy of the EAEU.

1. Non-compliance with the scale of individual electric power industries (Table 1).

Table 1. General indicators of the national electric power complexes of the EAEU Member States for 2016

\begin{tabular}{|c|c|c|c|c|c|}
\hline Indicator & $\begin{array}{l}\text { Republic of } \\
\text { Armenia }\end{array}$ & $\begin{array}{c}\text { Republic of } \\
\text { Belarus }\end{array}$ & $\begin{array}{l}\text { Republic of } \\
\text { Kazakhstan }\end{array}$ & $\begin{array}{l}\text { Republic of } \\
\text { Krygryztan }\end{array}$ & Russia \\
\hline $\begin{array}{l}\text { Installed power, } \\
\mathrm{GW}\end{array}$ & 3,2 & 9,7 & 21,3 & 3,6 & 243,2 \\
\hline $\begin{array}{l}\text { Consumption, } \\
\text { billion } \mathrm{kWh}\end{array}$ & 6,6 & 36,6 & 90,8 & 13,3 & 1060,2 \\
\hline $\begin{array}{c}\text { Production, billion } \\
\mathrm{kWh}\end{array}$ & 7,8 & 34,0 & 90,8 & 12,7 & 1067,5 \\
\hline $\begin{array}{c}\text { Imports, billion } \\
\mathrm{kWh}\end{array}$ & 0,2 & 2,8 & 1,8 & 0,8 & 8,8 \\
\hline $\begin{array}{c}\text { Exports, billion } \\
\mathrm{kWh}\end{array}$ & 1,4 & 0,2 & 1,8 & 0,2 & 16,1 \\
\hline $\begin{array}{l}\text { The length of the } \\
\text { transmission lines } \\
22 \mathrm{kV} \text { and above, } \\
\text { thousand km. }\end{array}$ & 1,44 & 7,0 & 24,5 & 2,3 & 130 \\
\hline
\end{tabular}

The table shows that the capacity of the electric power complex of the Russian Federation is 75 times more than the UES of the Republic of Armenia, 65 times more than the UES of the Kyrgyz Republic, 25 times more than the UES of the Republic of Belarus and 10 times more than the UES of the Republic of Kazakhstan. In this regard, there is a risk that the convergence and operation of the Common Electricity Energy Market will occur according to the rules of one state, which ultimately will lead to the refusal to participate in the market for smaller energy systems $[3 ; 4 ; 6]$.

2. Distinction of industry structures and quasi competitive markets of electric energy. For example:

- in the Republic of Armenia, the electric power industry is divided into competitive and monopolistic activities, while the grid company buys electric energy and sells it at the tariffs set by the state, and the market operates according to the "only buyer - seller" scheme;

- in the Republic of Belarus, the electric power industry is managed by the state vertically integrated company Belenergo, the tariffs for the population are set by the Council of Ministers, and for other consumers by the Ministry of Economy of the Republic of Belarus;

- in the Republic of Kazakhstan, there is a quasicompetitive electric energy market, but the pricing process is not transparent and not understandable for ordinary consumers; as part of the tariff formation, they use incentive factors, consumer price index, depreciation for the first year, uncontrollable costs for the first year;

- in the Republic of Kyrgyzstan, the electric power industry was also reformed, and in 2002 a quasicompetitive market was formed, but power plants with a capacity of more than $30 \mathrm{MW}$ remain in the ownership of a company with state participation of more than $93 \%$, $110-500 \mathrm{kV}$ networks were transferred to the national power grid company, $4-35 \mathrm{kV}$ in four regional network companies. Tariffs for electric energy are approved by the State Department for FEC at the Ministry of Economy of the Republic of Kyrgyzstan;

- in the Russian Federation there is a quasi- competitive market of electric energy, and the tariff for electric energy, it is considered to be, is formed on the market.
Thus, these problems associated with the different structure of national electric power industries and markets can be an obstacle in the process of convergence of the electric power industry of the EAEU member states $[3 ; 4 ; 18]$.

3. The next problem is the fragmentation of the electrical balance of the member states of the Eurasian Economic Union (Fig. 1).

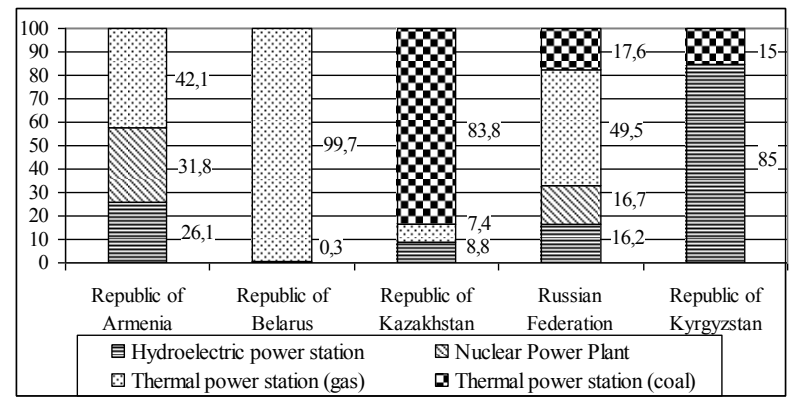

Fig. 1. Electrical balance of the EAEU Member States for 2016 , in percent

From the presented figure it is clear that the production capacity at which the generation of electrical energy is diverse, and all this affects the cost of electrical energy, which ultimately affects the final tariff for consumers. Moreover, such a capacity structure generates two problems presented below $[3 ; 4 ; 10 ; 11$; $12]$.

4. Tariffs for electric energy in the member states of the Eurasian Economic Union are different (Fig. 2).

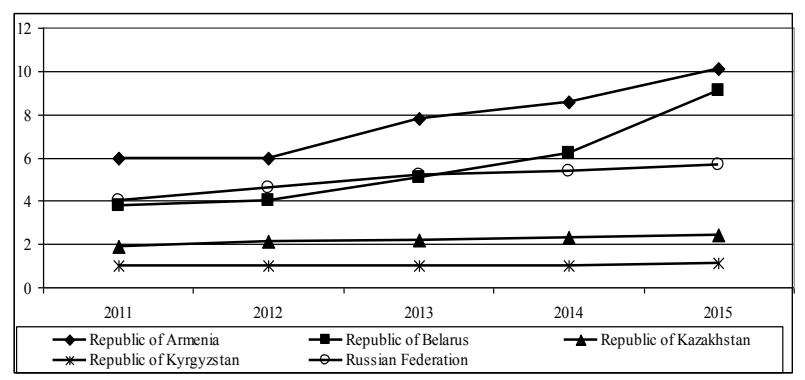

Fig. 2. The cost of electricity, cents US dollars / kWh

From the presented figure it is clear that the tariff for electricity is the cheapest in the Republic of Kyrgyzstan, and the highest figure in the Republic of Armenia and the Republic of Belarus. First of all, this is due to the fact that energy production in Kyrgyzstan takes place at hydropower plants, in which the raw material component in cost is virtually absent, while in Armenia and Belarus this figure increases due to the use of purchased fuel, mainly on the Russian fuel and energy market [3; 4].

5. The Republic of Belarus expressed a particular opinion on the Concept for the Formation of the Common Electricity Market of the Eurasian Economic Union, referring to the fact that there is a need to create a Common Gas Market, and then an electricity market.

This step of the Republic of Belarus is understandable, since $99,7 \%$ of electric energy is generated on its territory, based on the use of gas, mainly Russian, and if the Common Market of Electricity is created before the gas market, the electric power 
industry of the Republic of Belarus may lose competitiveness. The demand for electric energy will be satisfied by the purchase of energy in the common market, mainly produced at Russian power plants $[3 ; 4$; $14]$.

6. Lack of common borders of the Republic of Armenia with the borders of the EAEU Member States. Armenia borders with Azerbaijan, Georgia, Iran and Turkey, military conflicts are constantly occurring in the territories of these countries, and the construction of power lines to connect the republic with the countries of the EEU can be a costly and high-risk event $[3 ; 4 ; 15]$.

Of course, all the problems identified will hinder the creation and effective functioning of the Common Electricity Market of the Eurasian Economic Union. In this regard, there is a need to develop mechanisms for the convergence of national electric power industries, which should be carried out through the following measures:

- creation of a supranational body with the participation of all interested parties, including sectoral ministries and departments, generation, networks, sales organizations, specialized scientific and educational institutions, organizations and associations responsible for the functioning and development of the national electric power industry;

- formation of the rules for the functioning of the Common Electricity Market considering the sectoral republican specifics, with a phased description of each process, mechanisms and timing of their implementation;

- harmonization of national legislation in the field of electric power industry;

- settlement of general technical regulations;

- development of legal regulations to regulate the further functioning and development of the supranational electric power industry;

- analysis of the technical condition of generating facilities and networks, the formation of forecasts of the flow of electrical energy through inter-system power lines, in order to reduce the use of inefficient production capacity;

- development of pricing mechanisms in the domestic market and the international market of electric energy;

- the formation of the concept of improving the technical and technological sustainability of national industries [3; $4 ; 16 ; 17]$.

Thus, the development of the electricity market of the Eurasian Economic Union is possible only if the states can make decisions on the development of this market on a parity basis, which can be achieved through the creation of specialized supranational electric power bodies, which will include representatives of interested parties from all states.

\section{Conclusions}

The development of new markets in the framework of a supranational union is a difficult and long-term process that can be realized not only on the basis of the opinions of the EAEU member states, but also considering the experience of creating such systems within other integration associations that successfully function on the world map.

\section{References}

1. S.Glazyev, V. Chushkin, S. Tkachuk, The European Union and the Eurasian Economic Community: similarities and differences in the processes of integration construction. (VIKOR MEDIA LLC, Moscow, 2013).

2. A. Gibadullin Mechanisms of convergence of national electric power complexes in the framework of the Eurasian Economic Union. Russian Foreign Economic Journal, 2018, vol. 2018, no 4, pp. 95-104.

3. A. Gibadullin, V. Pulyaev, Yu. Erygin, Conceptual directions of sustainable development of the Eurasian Economic Union. (Publishing house GUU, Moscow, 2018).

4. A. Gibadullin, Development of mechanisms for the convergence of national electricity markets in the framework of the creation of the Common Electricity Market of the Eurasian Economic Union. Actual problems of management in the fuel and energy sector 2017: materials of the I All-Russian Scientific and Practical Conference. (State University of Management, Moscow, 2017).

5. T. Mansurov, Creating common energy markets of the Eurasian Economic Union. Common Electricity Market, Energy Market, 2015, vol. 5, pp. 26-33.

6. A. Gibadullin, V. Pulyaeva, Y. Yerygin, The Need for a Digital Substation during the Digitalization of Energy. International Youth Scientific and Technical Conference Relay Protection and Automation, RPA, 2018, no 8537223 .

7. A. Gibadullin, S. Bortalevich, Y. Yerygin, Dynamic Invariance of the Electric Power System. Advances in Economics, Business and Management Research, 2019, vol. 47, pp. 299-302.

8. E. Kamchatova, A. Vasilieva, N. Lyasnikov, M. Dudin, N. Vysotskaya, Eneggy saving management in urban economy and industry. International Journal of Civil Engineering and Technology, 2018, vol. 9, no 6, pp. 1423-1429.

9. N. Kharitonova, E. Kharitonova, V. Pulyaeva, Prospects for application of new information technologies in contemporary higher economic education. Advances in Intelligent Systems and Computing, 2019, vol. 726, pp. 1091-1100.

10. Yu. Linnik, V. Sherstkin, V. Linnik, Integral criterion of coal seam breakability. Gornyi Zhurnal, 2015, vol. 8, pp. 37-41.

11. Yu. Linnik, V. Linnik, F. Garifullin, Loading and durability of cutter holders in case of wear of coal production combine cutter slots. Ugol', 2018, vol. 11(1112), pp. 24-30. 
12. Yu. Linnik, V. Linnik, The hypothesis on the energy assement as for operational safety of function elements in coal mining machines. Naukovyi Visnyk Natsionalnoho Hirnychoho Universytetu, 2015, vol. 3, pp. 51-55.

13. Yu. Romanova, I. Pavlova, N. Barkova, I. Korneeva, Use of digital technologies in the construction and management of industrial and civil objects. International Journal of Civil Engineering and Technology, 2018, vol. 9, no 6, pp. 1404-1410.

14. A. Merenkov, Digital economy: transport management and intelligent transportation systems. Emanagement, 2018, no 1, vol. 1, pp. 12-18. DOI: 10.26425/2658-3445-2018-1-12-18.

15. V. Linnik, Yu. Linnik, Priority directions of innovative development in oil and gas complexat the Siberian Federal District. Upravlenie, 2019, vol. 7, no 1, pp. 40-49. DOI: 10.26425/2309-3633-2019-1-40-49.

16. D. Morkovkin et al 2019 IOP Conf. Ser.: Mater. Sci. Eng. 537042064.

17. A. Gibadullin et al 2019 IOP Conf. Ser.: Mater. Sci. Eng. 537042031.

18. V. Vorontsov, A. Timofeev, F. Sharipov, Current trends in the coal market in China in the second half of 2018. Ugol', 2019, vol. 4(1117), pp. 110-112. http://dx.doi.org/10.18796/0041-5790-2019-4-110-112 